\title{
Stevens Johnson Syndrome in a patient with systemic lupus erythematosus on tuberculostatic treatment
}

\author{
Alius Cahyadi, Karina Anindita, Maria R. Iryaningrum \\ Department of Internal Medicine, Faculty of Medicine, Atma Jaya University - Atma Jaya Hospital, Jakarta, Indonesia
}

\begin{abstract}
Abstrak
Seorang wanita usia 22 tahun datang dengan keluhan utama timbul bercak kemerahan dan rasa gatal pada wajah sejak 5 hari sebelum masuk rumah sakit. Keluhan lainnya adalah timbul bengkak pada kedua tungkai, nyeri tenggorokan, dan batuk. Pasien sedang dalam pengobatan untuk lupus eritematosus sistemik dan tuberkulosis paru (sejak 12 hari yang lalu). Pada pemeriksaan fisik, pasien kompos mentis, hemodinamik stabil, dengan edema anasarka, lesi multipel makulo purpura yang tersebar pada tubuhnya, konjungtivis pada kedua mata, lesi multipel ulserasi di rongga mulut, dan tampak eritema pada mukosa genitalia. Hasil laboratorium menunjukkan anemia, lekopenia, hipoalbuminemia, proteinuria. Kami mencurigai pasien ini menderita sindrom Stevens Johnson akibat obat antituberkulosis. Selama perawatan, kami menghentikan pemberian obat antituberkulosis, dan memberikan metilprednisolon parenteral, serta terapi suportif lainnya. Pasien diizinkan untuk rawat jalan setelah terjadi perbaikan klinis dan dapat mobilisasi sendiri. (Med J Indones. 2012;21:235-9)
\end{abstract}

\begin{abstract}
A 22-year-old woman was admitted to the hospital because of 5-days history of redness and itch on her face. Additional complains were swelling on her feet, sore throat, and cough. Patient was on treatment for systemic lupus erythematosus and pulmonary tuberculosis (since 12 days). On physical examination, patient was alert, stable hemodynamic, anasarca edema, multiple purpuric macules lesion spread on her body, conjunctivitis of both eyes, multiple oral ulcers, erythema on genital mucosa. Laboratory results were anemia, leucopenia, hypoalbuminemia, proteinuria. We suspected this patient as Stevens Johnson syndrome due to tuberculostatic drugs. During treatment, we stopped the tuberculostatic drugs, and gave her parenteral methylprednisolone, with other supportive treatments. The patient was discharge after improvement of clinical condition and capable of self mobilization. (Med J Indones. 2012;21:235-9)
\end{abstract}

Keywords: Stevens Johnson Syndrome, systemic lupus erythematosus

Systemic lupus erythematosus (SLE) is a multisystem disease that is caused by antibodies productions and complement-fixing immune complex deposition that result in tissue damage. These antibodies are present for a few years before the first clinical symptoms appear. Difference specific organ targeted can manifest in various clinical manifestations and assigned with remission and exacerbation. Systemic glucocorticoid is one of choice in management of severe manifestation of SLE, included lupus nephritis. Using this drug for a long time and large doses could make the patient prone to the infection. Treatment for manage this infection has risks, for example is allergic reaction.

SLE is an autoimmune disease with various clinical manifestations which has autoantibodies to the components of the cell nucleus. The pathologic findings of SLE are manifested by inflammation, blood vessel abnormalities including vasculopathy and vasculitis, and immune-complex deposition. These deposits consist of $\operatorname{IgM}$, IgG, and IgA, as well as complement components. The immune-complex is delivered to all organs, such as kidney (lupus nephritis), skin lesions (inflammation and degeneration at the dermalepidermal junction, or necrotizing vasculitis), central nervous system (neuropsychiatric manifestation), cardiovascular system (pericarditis is the most common), pleura and lungs (acute lupus pneumonitis, pleuritis), gastrointestinal (oral cavity, esophagus, liver). Besides inherited and hormonal factors as the predisposition for individual become SLE, other external, environmental and temporal variations are also contribute. These factors comprise of infection (that can induce specific response), stress (which potentialy change neuroendocrine system leading to immune cell dysfunction), diet (influence production of inflammatory mediators), toxin including drugs (change cellular response and antigen immunogenicity), physical agents such as sunlight (inflammation and tissue damage). The impingement of these factors on the predisposed individual is likely to be highly variable, providing the disease's heterogeneity and its alternating periods of flare and remission. ${ }^{1-7}$

Tuberculosis (TB) is one of the infectious diseases that are still endemic in Indonesia. Most of TB cases are spread by air borne. Pulmonary TB is the most prevalence in TB infections. Treatment for pulmonary TB is based on WHO guideline which is treated with tuberculostatic drugs. First line tuberculostatic drugs are isoniazid, rifampicin, ethambutol, and pyrazinamide. There are some adverse effects of these drugs from 
the minor effects (nausea, vomiting, gastrointestinal upset) to the major effects (erythema multiform). Stevens Johnson Syndrome (SJS) is an acute severe mucocutaneous reaction, which mostly induced by drugs and sometimes by infections. This syndrome can manifest on skin (erythema, vesicle/ bullae, purpura) and more than one of mucosal sites (oral, conjunctiva, and anogenital). ${ }^{1-3,8,9}$ The principles of management of SJS is discontinuation of suspected drugs along with supportive therapies.

The pathomechanisms of SJS are only partially understood. SJS is viewed as a cytotoxic immune reaction aimed at the destruction of keratinocytes expressing foreign (drug related) antigens. The characteristic lag phase between exposure and disease onset (1 to 45 days; mean, 14), which tends to be much briefer at repeated exposure, also suggests an immune pathogenesis. ${ }^{8}$

SJS is most often (more than 50\%) elicited by drug allergies, and the rest of cases are linked to infection, vaccination, or graft-versus-host disease. Some groups of drugs are known as common triggers of SJS such as antibacterial sulfonamides, anticonvulsants, and nonsteroidal anti-inflammatory drugs (NSAIDs); followed by antimalarials, allopurinol, and tuberculostatics. Infectious agents that can induce SJS are Mycoplasma pneumoniae, histoplasmosis, adenovirus infection, gram-negative septicemia. Genetic factor, synergistic effect (viral infection and drugs) and drugs interaction, physical agents such as UV light and X-ray are also the risk factors of SJS. SJS is prone to occur in patient with multiple comorbid diseases, particularly those that activate the immune system, such as collagen vascular disease, neoplasia, lymphoma, acute graft-versus-host disease, etc. ${ }^{8,9}$

Generaly, SJS begins with a non-specific prodromal symptoms of 1 to 14 days: fever, malaise, headache, rhinitis, cough, sore throat, chest pain, vomiting, diarrhea, myalgia, and arthralgia. The medications given to release these prodromal symptoms may cause difficulties in determining the offending factor. A macular or morbiliform rash appears first on the face, neck, central trunk area, and spread to the extremities and then the rest of the body. The lesions rapidly increase in number and size to the maximal disease expression within 4 to 5 days. In SJS there are three abnormalities including skin, orifice mucous layer, and eye lesion. Skin lesion can manifest as erythema, vesicle, bullae, and purpura. Oral and genital mucosal lesions often occure as hemorrhagic crusts covering the lips. Eye involvement most often include catarrh conjunctivitis, purulent conjunctivitis, corneal ulceration. ${ }^{8,9}$

Administration of high dose corticosteroid remains the cornerstone of SJS treatment, eventhough some literatures argue whether corticosteroid are really needed. In this paper, we illustrate a case of SJS which occured in SLE patient after taking tuberculostatic drugs. The dilemma appears regarding the risk of flare up of tuberculosis during steroid treatment while tuberculostatic drugs should be discontinued.

\section{CASE ILLUSTRATION}

A 22-year-old woman was admitted to Atma Jaya Hospital with a chief complain of 5-days history of redness and itching on her face. Additional complains

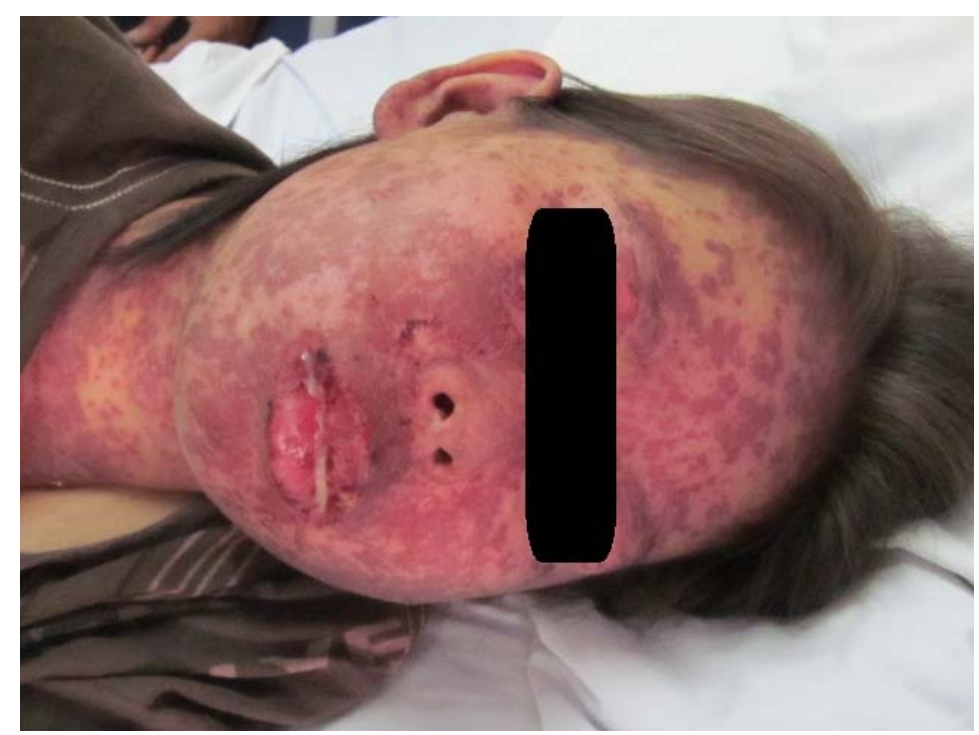

Figure 1. Multiple maculopurpura lesions on face 

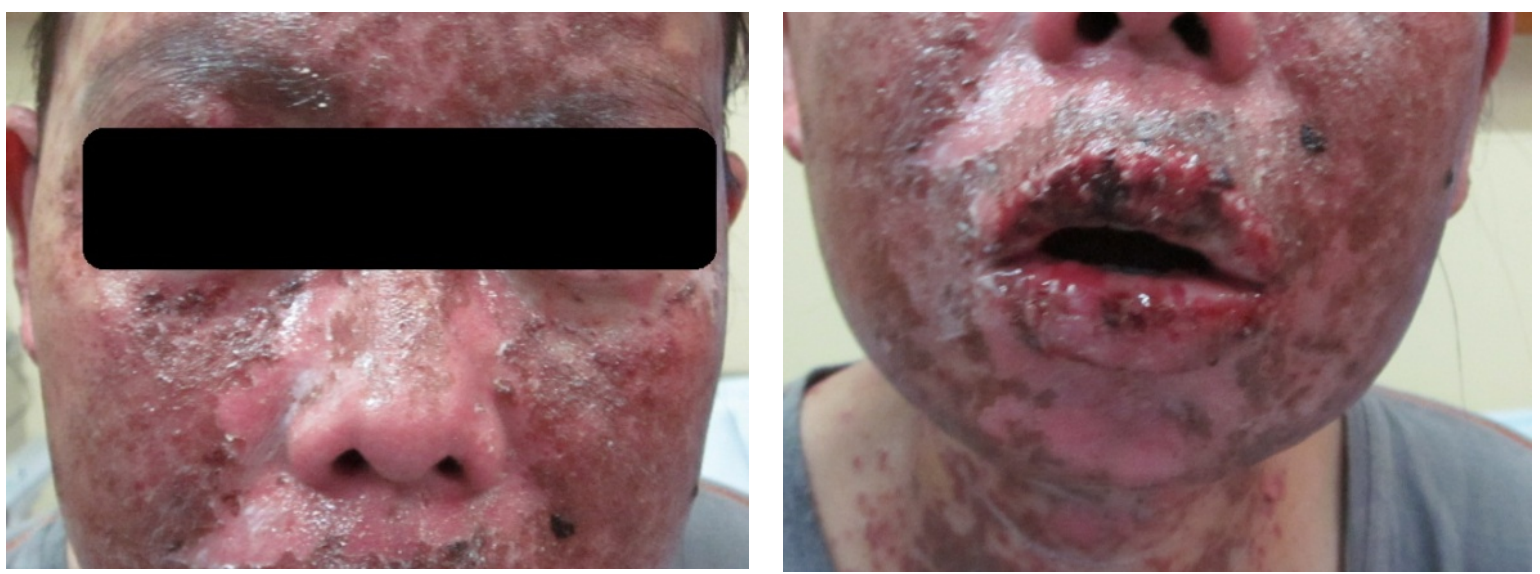

Figure 2. The development of lesions on face

were swelling on her feet, sore throat, and cough. This patient was first diagnosed as systemic lupus erythematosus (SLE) since three years and still consumed the maintenance drugs. Twelve days before she came, she had been diagnosed as pulmonary tuberculosis (TB) and was given the tuberculostatic treatment. On physical examination, patient was fully alert with stable hemodynamic, anasarca edema, with multiple purpuric macule lesions spread on her face, neck, chest, trunk, and both arms, conjunctivitis of both eyes, multiple oral ulcers, and erythema on genital mucosa.

Laboratory results revealed anemia $(\mathrm{Hb} \quad 9.1 \mathrm{~g} /$ $\mathrm{dL}$ ), leucopenia (leucocyte count $3500 / \mu \mathrm{L}$ ), hypoalbuminemia (albumin $1.9 \mathrm{~g} / \mathrm{dL}$ ), and proteinuria $(500 \mathrm{mg} / 24 \mathrm{~h})$. We diagnosed this patient as SJS which is suspected to be due to tuberculostatic drugs. During treatment we stopped all the tuberculostatic drugs and treated her with parenteral methylprednisolone $2 \mathrm{mg} /$ $\mathrm{kg} / \mathrm{d}$. We also gave her other supportive treatments, such as parenteral nutrition in early days, gastroprotector, eyes treatment, oral hygiene, skin moisturizer, and lips mucosal treatment.

During hospital treatment her clinical condition improved, and we started to taper off methylprednisolone doses until reaching the maintenance dose for SLE, and metylprednisolone was changed to oral route. The patient was stayed in the hospital for 25 days, and after she could tolerance oral feeding and capable of self-mobilization, she was allowed to discharge home. She was advised to visit internal medicine policlinic routinely as an outpatient.

During follow up in Internal Medicine policlinic, she had no clinical problem, so the tuberculostatic drug was then reinstituted started with low dose isoniazid. In the next follow up, there was not any clinical and laboratory abnormality, so she has been given adequate dosage of isoniazid with low dose ethambutol. After that, she did not come to our policlinic anymore. We have tried to contact her mobile phone, but the number was deactivated.

\section{DISCUSSION}

The incidence of SJS is estimated 2 to 3 cases per million population per year in Europe and United States. Most of these cases are adult patients, and the

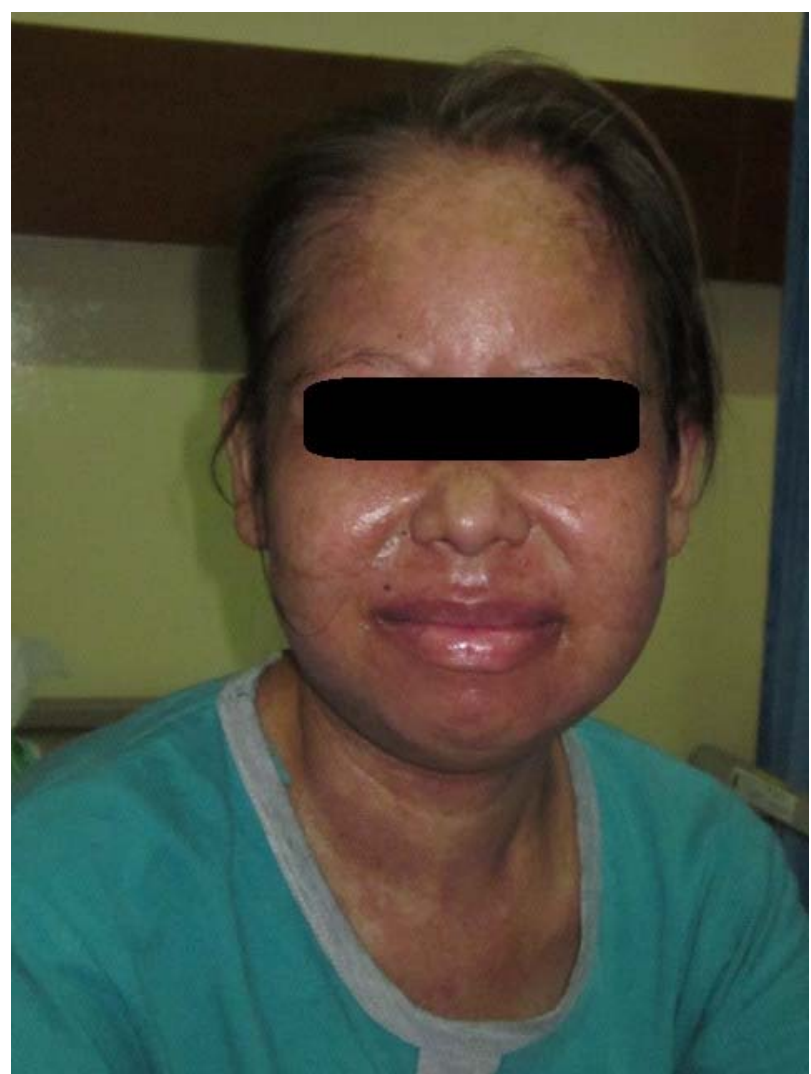

Figure 3. The condition when the patient was allowed to discharge home 
female to male ratio is approximately $2: 1$. In contrast, the incidence of SLE is approximately one in 2000 individuals, which is a disease of young woman (between the ages of 15 to 40), with a female to male ratio of 6 to 10:1.4,8 Approximately half a million of people in Europe and a quarter of people in USA have SLE. The majority of these patients are women in their childbearing years. ${ }^{7,10}$

In this case, the patient was a young reproductive woman that had been diagnosed as SLE since three years ago. She was still on SLE treatment with systemic oral glucocorticoid. Twelve days before she was admitted to the hospital, she was diagnosed with pulmonary $\mathrm{TB}$ and given tuberculostatic treatment according to WHO standard. However, after 7 days of treatment she complained about appearance of redness and itching especially on her face. She also complained about sore throat and cough. No history of fever, headache, vomiting, and diarrhea. The maculopapular rashes appear on her face, neck, chest, trunk, and extremities. There were also abnormalities on her eyes and genital mucosa. These clinical features were typically for SJS manifestation.

SLE cannot be cured, but we can control the development of acute severe flare up and suppress the symptoms to an acceptable level and prevent organ damage. Therapeutic choices depend on whether disease manifestations are life threatening or likely to cause organ damage justifying aggressive treatments, or whether manifestations are potentially reversible, thus we can chose the best approaches to prevent complications of disease. Conservative therapies for non life-threatening disease can be directed to suppress the symptoms. Analgesics (nonsteroidal ant inflammation drugs) and antimalarial (hydroxychloroquine, chloroquine, and quinacrine) are the mainstay. ${ }^{3}$ Meanwhile, the life threatening SLE manifestation or potentially causing organ damage can be treated with systemic glucocorticoid oral prednisone $0.5-2 \mathrm{mg} / \mathrm{kg} /$ day or equivalent dose. Pulse dose intravenous methylprednisolone sodium succinate 1000 $\mathrm{mg}$ daily in three consecutive days and followed by oral prednisone $0.5-1 \mathrm{mg} / \mathrm{kg} /$ day or equivalent dose can be given to this case. Cytotoxic or immunosuppressant agents (e.g. cyclophosphamide, mycophenolate, cyclosporine, azathioprine, and methotrexate) are other treatments that can be used in this case.

There are some adverse effects associated with these treatments. For example, the frequent adverse effects in using systemic glucocorticoid are emotional instability, glaucoma, cataract, peptic ulcer, osteoporosis, osteonecrosis, cushingoid feature (central obesity, striae, hypertension, diabetes mellitus, dyslipidemia), and increasing risks of infection. Infections in SLE are usually caused by intrinsic immune disregulation, and chronic use of immunosuppressive drugs. ${ }^{3,11}$

In this case, the patient had been diagnosed as SLE since three years, and she had lupus nephritis, so the patient is still on systemic glucocorticoid treatment. Prolong used of systemic glucocorticoid increase the risk of infection, including pulmonary TB. Tuberculostatic treatment in this patient was assumed to be the causes of drug eruption reaction (SJS).

Treatment for SJS is based on three cornerstones: identification and elimination the provocative agent, active therapy, and supportive treatment. Recently there are no generally accepted regimens or treatment guidelines for SJS and controlled therapeutic trials have ever been published. If SJS is suspected, the causative drugs should rapidly be identified and withdrawn, however does not immediately halt disease progression. The most likely offending drug is one that has been newly administered in the past 4 weeks and is known as a risk drug for SJS. Active treatments that can be used are systemic glucocorticoid (methyl prednisolone 1 to $2 \mathrm{mg} / \mathrm{kg}$ per day given orally), intravenous immunoglobulin $(0.2$ to $0.75 \mathrm{~g} / \mathrm{kg}$ per day for four consecutive days), cyclophosphamide, cyclosporine, $\mathrm{N}$-acetyl cysteine. For supportive treatment, wound dressing with gauze or hydrocolloid dressings, steroid and antibiotic eye drops, oral hygiene..$^{8,12}$

In this case, we firstly stop all tuberculostatic drugs. And the patient was given parenteral glucocorticoid, even though she had already on treatment with oral glucocorticoid. This is because there were multiple ulcer lesions in oral cavity so it was hard for the patient to open her mouth. This systemic glucocorticoid is useful for treatment of SJS as well as for SLE. After the clinical improvement, the dose of glucocorticoid can be tapered off to reach the optimal dose for the SLE. Then the patient was allowed to discharge home without tuberculostatic drugs. This is the dilemma for us, that this can increase the risk of the flare of her pulmonary TB. Recently, no literature said the most frequent tuberculostatic drugs that can induce SJS. Concerning this patient, the tuberculostatic drug was readministered by low dose isoniazid, followed by low dose ethambuthol. Since there was no sign of reappearance of SJS symptoms, both drugs were then administered with full dose. Unfortunately, the patient was lost to follow up.

In conclusion, SJS is a potentially fatal multiorgan disease with a strong etiologic link to some medications. 
SJS could happen in a patient with long time treatment of glucocorticoid even only a small dose. One of the adverse effects of this drug is incline the risk of infection. There is similarity in treatment of SLE and SJS which is systemic glucocorticoid.

\section{REFERENCES}

1. Hahn BH. Systemic lupus erythemathosus. In: Longo DL, Kasper DL, Jameson JL, Fauci AS, Hauser SL, Loscalzo J, editors. Harrison's principal of internal medicine. 18th ed. USA: The McGraw-Hill Companies, Inc.; 2012. p. 2724-35.

2. Tutuncu ZN, Kalunian KC. The definition and classification of systemic lupus erythematosus. In: Wallace DJ, Hahn BH, editors. Dubois' lupus erythematosus. 7th ed. USA: Lippincott Williams \& Wilkins; 2007. p. 16-20.

3. Hahn BH. Systemic lupus erythematosus. In: Fauci AS, Langford CA, editors. Harrison's rheumatology. 2nd ed. USA: The McGraw-Hill Companies, Inc.; 2010. p. 66-81.

4. Pisetsky DS. Systemic lupus erythematosus: B. Epidemiology, pathology, and pathogenesis. In: Klippel $\mathrm{JH}$, Stone JH, Crofford LJ, White PH, editors. Primer on the rheumatic disease. 13th ed. USA: Springer Science+Bussiness Media, LLC; 2008. p. 319-26.

5. Buyon JP. Systemic lupus erythematosus: A. Clinical and laboratory features. In: Klippel JH, Stone JH, Crofford LJ, White PH, editors. Primer on the rheumatic disease. 13th ed. USA: Springer Science+Bussiness Media, LLC; 2008. p. 303-18.
6. Ruiz-Irastorza G, Olivares N, Ruiz-Arruza I, MartinezBerriotxoa A, Egurbide MV, Aguirre C. Predictors of major infections in systemic lupus erythematosus. Arthritis Res Ther. 2009;11(4):1-8.

7. Schulz SW, Derk CT. The gastrointestinal manifestations of systemic lupus erythematosus: a survey of the literature. The Open Autoimmunity Journal. 2009;1:10-26.

8. Fritsch PO, Maldonado RR. Erythema multiforme, StevensJohnson syndrome, and toxic epidermal necrolysis. In: Freedberg IM, Eisen AZ, Wolff K, Austen KF, Goldsmith LA, Katz SI, editors. Fitzpatrick's dermatology in general medicine. 6th ed. USA: The McGraw-Hill Companies, Inc.; 2003.

9. Djuanda A, Hamzah M. Sindrom Stevens-Johnson. In: Djuanda A, Hamzah M, Aisah S, editors. Ilmu penyakit kulit dan kelamin. 4th ed. Jakarta: Balai Penerbit FKUI; 2005. p.163-5. Indonesian.

10. Bertsias G, Loannidis JPA, Boletis J, Bombardieri S, Cervera R, Dostal C, et al. EULAR recommendations for the management of systemic lupus erythematosus. Report of a Task Force of the EULAR Standing Committee for International Clinical Studies including Therapeutics. Ann Rheum Dis. 2008;67:195-205.

11. Manzi S, Kao AH. Systemic lupus erythematosus: C. Treatment and assessment. In: Klippel JH, Stone JH, Crofford LJ, White PH, editors. Primer on the rheumatic disease. 13th ed. USA: Springer Science+Bussiness Media, LLC; 2008. p. 327-38.

12. Tyagi S, Kumar S, Kumar A, Singla M, Singh A. StevensJohnson syndrome- a life threatening skin disorder: a review. J Chem Pharm Res. 2010;2(2):618-26. 